\title{
Evaluation of the Efficacy of Medium Protein Diet, Turmeric and Arabic Gum on Chronic Renal Failure

\author{
Ebtesam Fath M. Omar ${ }^{1}$ and Doaa Ibrahim Mohamed Kabil ${ }^{2}$
}

\begin{abstract}
Renal failure is accompanied by oxidative stress, which is caused by enhanced production of reactive oxygen species and impaired antioxidant defense. Turmeric and Arabic gum have antioxidant activities and medicinal properties. This study aimed to investigate the effect of two levels of turmeric and Arabic gum and their combination in the presence of medium protein diets on rats with chronic renal failure. A total of (54) rats weighting $200 \pm 10 \mathrm{~g}$ were fed on basal diet for 7 days for acclimatization. Rats divided into two main groups, the first main group $(n=6)$ fed on basal diet for 8 weeks (Negative Control), while the second main group fed on basal diet containing $2 \%$ L- arginine (arginine diet) for 4 weeks to induce chronic renal failure then the second main group divided into 8 subgroups $(n=6)$ for 4 weeks as following: Subgroup (1): fed on arginine diet containing $14 \%$ protein and used as a positive control group. Subgroup (2): fed on arginine diet containing 7\% protein, and used medium protein diet group (MPD).Subgroups (3 and 4): fed on MPDs containing 3\% and 6\% Arabic gum, respectively. Subgroups (5 and 6): fed on MPDs containing $1 \%$ and $2 \%$ turmeric, respectively. Subgroup (7): fed on MPD containing 3\% Arabic gum and 1\% turmeric. Subgroup (8): fed on MPD containing 6\% Arabic gum and 2\% turmeric. During the experimental period, rats were weighted weekly, feed intake and body weight gain were recorded. At the end of experimental period, rats were scarified; blood samples were collected centrifuged and frozen until analysis. Creatinine, urea nitrogen and uric acid, total protein, Na, K, AST, ALT, glucose and lipid profile were measured. Our results concluded that, all experimental diets had a positive effect on renal functions and the other complications resulted from CRF either alone or combined with medium protein diet especially with high levels. This effect may be due to antioxidant potential of turmeric and Arabic gum.
\end{abstract}

Keywords: Chronic renal failure- L- arginine- medium protein diet - turmeric -Arabic gum- kidney functionsglucose- lipid profile - liver enzymes.

\section{INTRODUCTION}

Kidneys are the critical target organs that performed many functions including keeping the blood clean and chemically balanced. Kidney functions depend on the ability of the kidneys to filter blood that is estimated using glomerular filteration rate. Progressive loss of kidney functions leads to chronic renal failure (Gerich et al. 2001). Chronic kidney disease is characterized by inability of kidney function to return to normal after acute kidney failure or progressive renal decline from disease (National Kidney Foundation, 2000). Chronic renal failure is defined by the presence of a marker of kidney damage, such as increasing of renal functions or a decrease glomerular filtration rate for three or more months (Christoph et al. 2002 and Hsu et al. 2004).

Arginine is classified as semiessential amino acid because the ability of the body to synthesize sufficient quantities to meet its needs which varies according to development age and incidence of disease or injury. Larginiecanbe catabolized in mammalian cell: nitric oxide synthesis, arginase, arginie: glycine amidiotransferase and arginine decarboxilase (Morris, 2004).Similarly, Baylis, (2006) confirmed that Larginine/nitric oxide pathway increased in liver and kidney diseases. The increased in nitric oxide production is attributed to dietary arginine and that causes renal failure. Dietary protein restriction affected positively the progression of renal disease (Pedrini et al. 1996) that may reduce decline in renal functions (Eyre et al. 2008), alleviates uremic symptoms (Maroni and Mitch 1997), and delay dialysis therapy (Brunori et al. 2007). Medium protein diet ameliorate inflammation; suppresses oxidative stress and proteinuria (Kim et al. 2010).

Arabic gum is an edible, dried sticky exudates from Acacia senegal (Leguminosae) (Younes et al. 1995). It is commonly used in food industry and pharmaceutical field as an emulsifier and preservative that rich in nonviscous soluble fiber (Ali et al. 2009). Arabic gum has long been used in Arab folk medicine to reduce both the frequency and the need for hemodialysis in patients with chronic renal failure. Additionally, Arabic gum has been shown to reduce urinary nitrogen excretion by increasing urea disposal in the cecum and lowers serum urea concentration in rat and human (Bliss et al. 1996), and has antioxidant properties that reduce nephrotoxicity against gentamicine(Al-Majed et al. 2002).

Turmeric (Curcuma longa L.) is a rhizomatous of the Zingiberaceae family, which is widely used as a

${ }^{1}$ Home Economic Dept., Faculty of Specific Education,

Alex. University, Egypt

${ }^{2}$ Home Economic Dept., "nutrition \&Food science"

Faculty of Specific Education, Tanta University, Egypt.

Received July 10, 2018, Accepted August 27, 2018 
spice and coloring agent and for its medicinal properties (Luthra et al 2001) as anti-cancer, anti-diabetic, liver protecting, antioxidant, anti-inflammatory, anti-bacterial (Prasad and Aggarwal 2011) and its biological activities (Joe et al. 2004). Turmeric is considered a strong antioxidant agent (Banerji and Banergee 2016 and Rozan et al. 2018) due to its content of phenolic compound as curcuimin, demethoxycurcumin, and bisdemethoxycurcumin (Kulkarni et al. 2012). There is a dearth of information providing scientific support for improvement of chronic renal failure by different supplements as turmeric and Arabic gum either individual or combination with medium protein diet. So current study was undertaken to investigate the role of medium protein diet, turmeric and Arabic gum against L- arginine -induced chronic renal failure.

\section{MATERIALS AND METHODS}

\section{Materials:}

Casein, minerals, vitamin mixture, cholin chloride and L-arginine were obtained from El- Gomhoria Company. Arabic gum Acacia Senegal, turmeric, corn starch, soybean oil and sucrose were purchased from local market, Cairo, Egypt. Adult male albino rats of Sprague Dawley strain were obtained from the Animal Colony, Food Technology Research Institute, Agriculture Research Center, Giza, Egypt.

\section{Methods:}

\section{Biological evaluation}

A total of (54) rats weighting $200 \pm 10 \mathrm{~g}$ were fed on basal diet for 7 days for acclimatization. Rats were divided into two main groups, the first main group $(\mathrm{n}=6)$ fed on standard diet for 8 weeks (Negative Control), while the second main group fed on basal diet containing $2 \%$ L- arginine (arginine diet) were for 4 weeks to induce chronic renal failure (Yokozawa et al. 2003), then the second main group divided into 8 subgroups $(n=6)$ for 4 weeks according to the following scheme:Subgroup (1): fed on arginine diet containing $14 \%$ protein and used as a positive control group.Subgroup (2):fed on arginine diet containing 7\% protein, and used as medium protein diet group (MPD). Subgroups(3 and 4): fed on MPDs containing 3\% and 6\% Arabic gum, respectively. Subgroups (5 and 6): fed on MPDs containing $1 \%$ and $2 \%$ turmeric, respectively. Subgroup (7): fed on MPD containing 3\% Arabic gum and $1 \%$ turmeric. Subgroup (8): fed on MPD containing $6 \%$ Arabic gum and 2\% turmeric. During the experimental period, rats were weighted weekly and feed intake was recorded daily. At the end of the experiment, body weight gain (BWG \%) was determined according to (Chapman et al. 1959).
At the end of the experiment period, rats were fasted overnight, then the rats were anaesthetized and sacrificed, and blood samples were collected from the aorta in dry centrifuge tube. The blood samples were centrifuged and serum was separated to estimate some biochemical parameters i.e. serum urea nitrogen according to Henry et al. (1974), uric acid content in serum according to the method described by (Haisman and Muller 1977), creatinine (Bartels and Bohmer 1971), L- Aspartate amine transferase (AST) and LAlanine amine transferase (ALT) activities (Reitman and Frankel 1975), total cholesterol (Richmond, 1973), Triglycerides (Wahalefeld 1974), high density lipoprotein- cholesterol HDL- C (Richmond method 1973), low density lipoprotein- cholesterol LDL-C and very low density lipoprotein-cholesterol VLDL-C (Hatch and Lees 1986), Serum glucose(Trinder, 1969), serum sodium was measured according to the colorimetric method of (Henry et al. 1974) and serum potassium was measured according to the colorimetric method of Henry (1964).

Kidneys were separated from each rat and weighted to calculate the kidney weight to body weight \%.The statistical analysis was carried out by using SPSS, PC statistical software (version 10.0; SPSS Inc, Chieago, USA). The results expressed as mean \pm SD. Data analyzed by one-way analysis of variance (ANOVA). The Differences between means were tested for significance using least significant difference (LSD) test at $(\mathrm{P}<0.05)$ (Steel and Torri, 1980).

\section{RESULTS AND DISCUSSION}

Effect of medium protein diet containing two levels from turmeric, Arabic gum and their combination on feed intake, body weight gain $\%$ and kidney weight/body weight $\%$ of rats suffering from chronic renal failure presented in Table (1). Long term feeding of L- arginine to rats produced significant decrease $\mathrm{p} \leq 0.05$ in feed intake, as compared to negative control group as indicated by Yokozawa et al. (2003). All experimental diets showed significant improvement in feed intake, as compared to CRF rats except rats fed on medium protein diet (MPD) only, which showed nonsignificant differences, as compared to CRF rats. On the other hand, the highest feed intake value was observed in CRF fed on MPD containing2\% turmeric, followed by MPD containing $1 \%$ turmeric respectively. This effect is may be due to the flavor of turmeric, which improve appetite of rats. These results are in agreement with findings of Lee et al. (2016) who confirmed that, supplementation of turmeric extract improved feed intake in CCL4 treated rats. 
Table 1. Effect of medium protein diet containing two levels from turmeric, Arabic gum and their combination on nutritional parameters and kidney weight of chronic renal failure rats

\begin{tabular}{|c|c|c|c|c|}
\hline \multicolumn{2}{|c|}{$\begin{array}{ll}\text { Groups } & \text { Parameters } \\
\end{array}$} & $\begin{array}{c}\text { Feed Intake } \\
\text { (g/day/rat) }\end{array}$ & $\begin{array}{c}\text { Body weight gain } \\
\text { BWG \% }\end{array}$ & $\begin{array}{c}\text { Kidney weight / } \\
\text { body weight } \%\end{array}$ \\
\hline \multirow{2}{*}{\multicolumn{2}{|c|}{ Control (-ve) }} & $17.833^{\mathrm{a}}$ & $28.510^{\mathrm{a}}$ & $0.438^{\mathrm{g}}$ \\
\hline & & \pm 1.169 & \pm 1.909 & \pm 0.036 \\
\hline \multirow{2}{*}{\multicolumn{2}{|c|}{ Control (+ve) }} & $13.000^{\mathrm{f}}$ & $9.325^{\mathrm{e}}$ & $0.905^{\mathrm{a}}$ \\
\hline & & \pm 0.894 & \pm 1.190 & \pm 0.074 \\
\hline \multirow{2}{*}{\multicolumn{2}{|c|}{ Only }} & $13.666^{\mathrm{ef}}$ & $15.525^{\mathrm{d}}$ & $0.758^{\mathrm{b}}$ \\
\hline & & \pm 0.516 & \pm 0.979 & \pm 0.046 \\
\hline \multirow{2}{*}{\multicolumn{2}{|c|}{ Containing $3 \%$ Arabic gum }} & $14.500^{\mathrm{cd} \mathrm{e}}$ & $17.595^{\mathrm{bc}}$ & $0.640^{c}$ \\
\hline & & \pm 0.547 & \pm 0.967 & \pm 0.052 \\
\hline \multirow{10}{*}{ 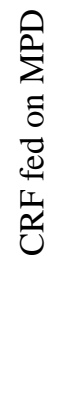 } & Containing $6 \%$ Arabic gum & $14.166^{\mathrm{de}}$ & $16.101^{\mathrm{cd}}$ & $0.563^{\mathrm{de}}$ \\
\hline & & \pm 0.752 & \pm 0.851 & \pm 0.056 \\
\hline & Containing $1 \%$ turmeric & $15.166^{\mathrm{bc}}$ & $17.585^{\mathrm{bc}}$ & $0.593^{\mathrm{cd}}$ \\
\hline & & \pm 0.750 & \pm 1.450 & \pm 0.041 \\
\hline & Containing $2 \%$ turmeric & $15.500^{\mathrm{b}}$ & $18.630^{\mathrm{b}}$ & $0.525^{\mathrm{ef}}$ \\
\hline & & \pm 0.547 & \pm 1.224 & \pm 0.044 \\
\hline & Containing 3\% Arabic gum & $14.666^{\mathrm{bcd}}$ & $17.721^{\mathrm{b}}$ & $0.517^{\mathrm{ef}}$ \\
\hline & and $1 \%$ turmeric & \pm 0.816 & \pm 0.968 & \pm 0.007 \\
\hline & Containing $6 \%$ Arabic gum & $14.166^{\mathrm{de}}$ & $17.151^{\mathrm{bc}}$ & $0.486^{\mathrm{fg}}$ \\
\hline & and $2 \%$ turmeric & \pm 0.752 & \pm 0.748 & \pm 0.024 \\
\hline
\end{tabular}

CRF. Chronic Renal Failure

MPD: Medium Protein Diet

Values are expressed as means \pm SD.

Values at the same column with different letters are significant at $\mathrm{P}<005$.

With respect to body weight gain\% (BWG \%), CRF rats showed significant decrease $\mathrm{p} \leq 0.05$ in $\mathrm{BWG} \%$, as compared to negative control group because of progressive weakness, weight loss, diarrhea and excessive muscle protein catabolism resulting in negative nitrogen balance (Yokozawa et al. 2003 and Giebisch 2007). While, significant increases were observed in body weight gain $\%$ in all treated groups , as compared to CRF rats especially MPD containing $2 \%$ turmeric and CRF group fed on MPD containing 3\% Arabic gum and $1 \%$ turmeric, respectively. The possible reason for increasing BWG\% might be due to increase in food intake. This effect was due to the presence of curcumin; the main ingredient of turmeric (Nayeri et al. 2017) which was due to the secretion of mucin which protect gastrointestinal tract against irritation and enhances intestinal lipase, sucrose and maltase activity ( Lee et al. 2003 and Platel and Srinivasan 1996). Recently, Lee et al. (2016) confirmed that, supplementation of turmeric extract improved body weight gain in CCL4 treated rats. In addition, Arabic gum increased weight gain in normal rats (Eqbal and Aminah 2014).

In concern with relative kidney weight, significant increase in the mean value of relative kidneys weight of L- arginine - fed rats were observed, as compared to negative control group. This, could be attributed to an increase in activity of inflammation of kidney tissue. All experimental diets resulted in marked reductions in relative kidney weight especially higher doses of (turmeric and Arabic gum) and the best result was recorded in MPD containing 6\% Arabic gum and 2\% turmeric. This effectiveness can be explained by antiinflammatory properties of turmeric and Arabic gum as demonstrated by Peter, (2000) who mentioned that turmeric is a good anti-inflammatory agent. Similarly, Antonyan et al. (2014) and Banerji and Banerjee (2016) demonstrated that turmeric has anti-inflammatory properties. Accordingly, our obtained results confirmed that treatment of CRF rats with supplementation of MPD containing 2\% turmeric agreed fairly with the results of Shivanoor and Dvid (2014) who concluded that feeding on turmeric- diet produced significant improvement in body weight gain and relative kidney weight in deltamethrin treated rats. Restriction in dietary protein intake was effective in decreasing inflammation and, suppressing oxidative stress (Kim et al. 2010). Moderate protein restriction improved oxidative stress and inflammation in Remnant Kidney Model (Tai and Ding 2010).

Effect of medium protein diet containing two levels from turmeric, Arabic gum and their combination on serum uric acid, urea nitrogen and creatinine of rats suffering from chronic renal failure illustrated in Table (2). Previous studies have resulted in considerable 
discussion of the link between renal diseases and oxidative stress, which lead to excessive generation of oxygen derived free radicals. These free radicals are highly reactive and injured lipids, protein, and nucleic acid resulting in structural and functional impairment (Schrier et al. 1988 and Yokozawa et al. 2003). Elevation in renal functions as a result of oxidative stress which plays a crucial role in the development in L-arginine - induced chronic renal failure. Impairment in radical- scavenging system in rats fed on L-arginine diet by decreasing in antioxidant activities has been demonstrated by (Yokozawa et al. 2003). Similarly, Sanders, (1995) reported that feeding on L-arginine-diet resulted in a progressive loss in renal functions. At the same subject, Baylis, (2006) confirmed that alteration in nitric oxide pathway is higher in L- arginie -fed rats as compared to casein -fed rats.

From our obtained results, it could be noticed that rats with chronic renal failure by administration of Larginine- diet produced significant impairment in renal functions, represented by significant increases in serum uric acid, urea nitrogen and creatinine levels as compared to negative control. As indicated by (Lee and Nieman, 1996 and Rahman et al. 2001) who reported that creatinine is known as a good indicator of renal functions; higher levels of creatinine mean there is obvious damage to functional nephrones. Current study indicated that all treated groups showed highly

Table 2. Effect of medium protein diet containing two levels from turmeric, Arabic gum and their combination on kidney functions of chronic renal failure rats

\begin{tabular}{|c|c|c|c|c|}
\hline \multirow{2}{*}{\multicolumn{2}{|c|}{ Parameters }} & \multicolumn{3}{|c|}{ Kidney functions (mg/dl) } \\
\hline & & Uric acid & Urea nitrogen & Creatinine \\
\hline \multirow{2}{*}{\multicolumn{2}{|c|}{ Control (-ve) }} & $1.265^{\mathrm{h}}$ & $26.295^{\mathbf{h}}$ & $0.563^{\mathrm{h}}$ \\
\hline & & \pm 0.038 & \pm 1.595 & \pm 0.029 \\
\hline \multirow{2}{*}{\multicolumn{2}{|c|}{ Control (+ve) }} & $3.486^{\mathrm{a}}$ & $67.105^{\mathrm{a}}$ & $2.816^{\mathrm{a}}$ \\
\hline & & \pm 0.098 & \pm 3.248 & \pm 0.104 \\
\hline \multicolumn{2}{|r|}{ Only } & $2.991^{\mathbf{b}}$ & $61.598^{b}$ & $2.425^{\mathrm{b}}$ \\
\hline \multirow{13}{*}{ 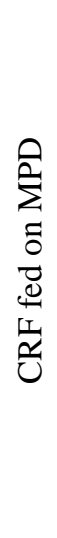 } & & \pm 0125 & \pm 3.265 & \pm 0.073 \\
\hline & \multirow[t]{2}{*}{ Containing $3 \%$ Arabic gum } & $2.555^{\mathrm{c}}$ & $55.103^{c}$ & $2.025^{\mathrm{c}}$ \\
\hline & & \pm 0.126 & \pm 3.510 & \pm 0.094 \\
\hline & \multirow[t]{2}{*}{ Containing 6\% Arabic gum } & $2.061^{\mathrm{e}}$ & $45.696^{\mathrm{e}}$ & $1.561^{\mathrm{e}}$ \\
\hline & & \pm 0.064 & \pm 2.315 & \pm 0.114 \\
\hline & \multirow[t]{2}{*}{ Containing $1 \%$ turmeric } & $2.301^{\mathrm{d}}$ & $50.631^{d}$ & $1.855^{\mathrm{d}}$ \\
\hline & & \pm 0.137 & \pm 3.447 & \pm 0.057 \\
\hline & \multirow[t]{2}{*}{ Containing $2 \%$ turmeric } & $1.888^{\mathrm{f}}$ & $41.481^{\mathrm{f}}$ & $1.328^{\mathrm{f}}$ \\
\hline & & \pm 0.117 & \pm 1.987 & \pm 0.100 \\
\hline & \multirow{2}{*}{$\begin{array}{l}\text { Containing } 3 \% \text { Arabic gum } \\
\text { and } 1 \% \text { turmeric }\end{array}$} & $2.008^{\mathrm{ef}}$ & $42.633^{\text {e f }}$ & $1.493^{\mathrm{e}}$ \\
\hline & & \pm 0.133 & \pm 1.824 & \pm 0.047 \\
\hline & \multirow{2}{*}{$\begin{array}{l}\text { Containing } 6 \% \text { Arabic gum } \\
\text { and } 2 \% \text { turmeric }\end{array}$} & $1.533^{\mathrm{g}}$ & $36.466^{\mathrm{g}}$ & $1.066^{\mathrm{g}}$ \\
\hline & & \pm 1.225 & \pm 2.080 & \pm 0.108 \\
\hline
\end{tabular}

CRF:Chronic Renal Failure MPD:Medium Protein Diet

Values are expressed as means \pm SD.

Values at the same column with different letters are significant at $\mathrm{P}<0.05$. significant reductions in all biomarkers of renal functions including (uric acid, urea nitrogen and creatinine) in comparable to CRF rats. Supplementation with MPD with combination of (6\% Arabic gum and $2 \%$ turmeric) showed highly significant reductions in renal functions in comparable to other treated groups and CRF rats.

These results were in consistent with earlier findings which confirmed that restriction in dietary protein intake has antioxidant effect in CKD in animals and human (Nankivell et al. 1994 and Stenvinkel et al. 1998), effective in improvement of renal functions (Eyre et al. 2008) and delaying the progression of renal disease and dialysis therapy (Brunori et al. 2007). Medium protein diet ameliorates inflammation, suppresses oxidative stress and reduces proteinuria in chronic renal failure rats (Kim et al. 2010).

Moderate protein restriction improved oxidative stress, inflammation in Remnant Kidney Model (Tai and Ding 2010). In this sense, (Castaneda et al. 2013) reported that restriction in dietary protein intake, as low protein diet can be effective to reduce uremia in patients with chronic renal failure. Recently, feeding on medium protein diet significantly reduced renal failure by $42 \%$ in diabetic elderly with chronic kidney disease (Giordano et al. 2014). 
Ki Haw and Keum Ran (2005) reported that curcumin produced improvement in renal functions by reducing levels of urea nitrogen and creatinine in $\mathrm{CCl} 4$ treated rats. Recently, (Rozan et al. 2018) mentioned that curcumin has antioxidant activity. Also, Shivanoor and David (2014) presumed that treatment of turmeric diet produced significant reductions in serum urea nitrogen, creatinine and uric acid levels in deltamethrin treated rats and improved antioxidant enzymes. Similarly, Khajehdehi et al. (2012) reported that turmeric has antioxidant activity and slowing the progression of chronic kidney diseases. This antioxidant effect of turmeric due to its content of flavenoids which acts as antioxidant agent (Gills 1992), and phenolic compounds (Naksuriya et al. 2014). Moreover, Biswas et al . (2005) reported that turmeric has antioxidant activity by modulating GSH levels scavenging oxygen free radicals. In addition, turmeric inhibits oxidative damage in mice, increases antioxidant enzymes, improves kidney tissue and repairs histological alterations of kidney (Shivanoor and David 2014).

Similarly, Arabic gum lowered urinary nitrogen excretion by increasing urea disposal in the cecum and lowers serum urea concentration in rat and human (Bliss et al. 1996). Arabic gum has antioxidant capacity and nephroporotective effect that is why it has been demonstrated in folk medicine to decrease need to hemodialysis in chronic renal failure patients and reduce nephrotoxicity against gentamicin (Al-Majed et al. 2002). Mahmoud et al. (2012) demonstrated that supplementation of Arabic gum improved renal dysfunction in adenine-induced chronic renal failure by decreasing serum creatinine, urea nitrogen and uric acid.

Experimentally, Arabic gum has been demonstrated as a strong antioxidant that improved renal functions (Ali et al. 2013), clinically, Arabic gum has been used in chronic renal failure patients. In addition, Ahmed et al. (2015) reported that Arabic gum acts as a strong antioxidant against reactive oxygen species by increasing superoxide dismutase, catalase and glutathione peroxidase and decrease in gmalondialdehyde.

The effect of medium protein diet containing two levels from turmeric, Arabic gum and their combination on serum protein, $\mathrm{Na}$ and $\mathrm{K}$ of chronic renal failure rats presented in Table (3).

Table 3. Effect of medium protein diet containing two levels from turmeric, Arabic gum and their combination on serum protein, $\mathrm{Na}$ and $\mathrm{K}$ of chronic renal failure rats

\begin{tabular}{|c|c|c|c|c|}
\hline \multicolumn{2}{|c|}{$\begin{array}{ll}\text { Groups } & \text { Parameters } \\
\end{array}$} & $\begin{array}{c}\text { Protein } \\
(\mathrm{g} / \mathrm{l})\end{array}$ & $\begin{array}{c}\mathrm{Na} \\
\mathrm{mmol} / \mathrm{l}\end{array}$ & $\begin{array}{c}\mathrm{K} \\
\mathrm{mmol} / \mathrm{l}\end{array}$ \\
\hline \multirow{2}{*}{\multicolumn{2}{|c|}{ Control (-ve) }} & $6.321^{\mathrm{g}}$ & $130.051^{\mathrm{a}}$ & $3.408^{\mathrm{h}}$ \\
\hline & & \pm 0.105 & \pm 3.849 & \pm 0.087 \\
\hline \multirow{2}{*}{\multicolumn{2}{|c|}{ Control (+ve) }} & $7.832^{\mathrm{a}}$ & $99.873^{\mathrm{g}}$ & $5.805^{\mathrm{a}}$ \\
\hline & & \pm 0.110 & \pm 3.812 & \pm 0.127 \\
\hline \multirow{2}{*}{\multicolumn{2}{|c|}{ Only }} & $7.533^{b}$ & $106.116^{\mathrm{f}}$ & $5.215^{\mathrm{b}}$ \\
\hline & & \pm 0.062 & \pm 3.639 & \pm 0.145 \\
\hline \multirow{2}{*}{\multicolumn{2}{|c|}{ Containing $3 \%$ Arabic gum }} & $7.330^{\mathrm{c}}$ & $111.383^{\mathrm{e}}$ & $4.578^{c}$ \\
\hline & & \pm 0.071 & \pm 2.942 & \pm 0.125 \\
\hline \multirow{10}{*}{ 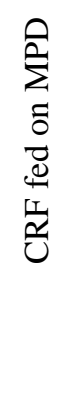 } & Containing $6 \%$ Arabic gum & $6.861^{\mathrm{e}}$ & $116.423^{\mathrm{cd}}$ & $4.143^{\mathrm{e}}$ \\
\hline & & \pm 0.030 & \pm 3.944 & \pm 0.085 \\
\hline & Containing $1 \%$ turmeric & $7.131^{\mathrm{d}}$ & $114.018^{\mathrm{de}}$ & $4.313^{\mathrm{d}}$ \\
\hline & & \pm 0.086 & \pm 3.076 & \pm 0.061 \\
\hline & Containing $2 \%$ turmeric & $6.857^{\mathrm{e}}$ & $118.936^{\mathrm{c}}$ & $3.938^{\mathrm{f}}$ \\
\hline & & \pm 0.061 & \pm 3.281 & \pm 0.074 \\
\hline & Containing $3 \%$ Arabic gum and & $6.710^{f}$ & $117.953^{\mathrm{cd}}$ & $4.073^{\mathrm{e}}$ \\
\hline & $1 \%$ turmeric & \pm 0.042 & \pm 1.880 & \pm 0.088 \\
\hline & Containing $6 \%$ Arabic gum and & $6.412^{\mathrm{g}}$ & $123.893^{b}$ & $3.638^{\mathrm{g}}$ \\
\hline & $2 \%$ turmeric & \pm 0.130 & \pm 2.770 & \pm 0.121 \\
\hline
\end{tabular}

Na: Sodium

CRF:Chronic Renal Failure K: Potassium

MPD:Medium Protein Diet

Values are expressed as means \pm SD.

Values at the same column with different letters are significant at $\mathrm{P}<0.05$. 
Adverse effects of chronic renal failure is proteinuria; as demonstrated by earlier study of Adams et al. (1994) who reported that feeding on high amount of protein significantly increased glomerular filtration rate and proteinuria. That is why; chronic administration of L- arginine produced elevated serum total protein in combatable to negative control group. Serum total protein levels were significantly decreased in all experimental diets, as compared to CRF rats especially higher doses of Arabic gum and turmeric when supplemented to MPD. The best result was recorded in experimental MPD containing 6\% Arabic gum and 2\% turmeric. These results are in going along with Trachtman et al. (1996) who mentioned that treatment with antioxidant improved renal functions and decreased protein urea, likewise, Chan et al. (1998) demonstrated that higher doses of antioxidant reduced proteinuria.

Also, Ali et al. (2013) who mentioned that administration of Arabic gum significantly reduced proteinuria in adenine- induced chronic renal failure in rats. Other metabolic abnormalities of chronic renal failure is hyponatremia (Henry et al. 1991). Also, Hilton et al. (1998) reported that patients with chronic renal failure have lower excretion of potassium (hyperkalemia) and higher excretion of sodium (hyponatremia).With respect to our results indicating the relationship between sodium and potassium in chronic renal failure rats and treated groups. From obtained results, it could be deduced that chronic administration of L- arginine caused abnormal changes in serum sodium and potassium levels as compared to negative control group. All treated rats showed significant differences as rising of sodium and reduction in potassium values as compared to CRF untreated rats. Treatment with feeding on (MPD containing 6\% Arabic gum and 2\% turmeric) and (MPD containing 3\% Arabic gum and $1 \%$ turmeric)showed highly significant improvement respectively as compared to positive control group.

These results are in line with those obtained by Hus and Chertow (2002) who mentioned that patients with chronic renal failure have metabolic acidosis, which induces efflux potassium $(\mathrm{K}+)$ from cells. Also, Nguyen and Krutz (2005) and Giebisch (2007) who revealed that elevated levels of serum potassium are related to chronic renal failure. Moderate protein diet does not lead to malnutrition and ameliorates metabolic acidosis (Eyre et al. 2008). Restriction in dietary protein intake was effective in, suppressing oxidative stress and reducing proteinuria (Kim et al. 2010). In this sense, moderate protein restriction improved oxidative stress, and proteinuria in Remnant Kidney Model (Tai and Ding 2010).

Data in Table (4) showed the effect of medium protein diet containing two levels from turmeric, Arabic gum and their combination on serum glucose and liver enzymes of rats suffering from chronic renal failure.

The relationship between oxidative stress and progression of hyperglycemia was reported by (Curcio et al. 1995). Yokozawa et al. (2003) demonstrated that administration of L-arginine produced elevation of glucose levels as complication of chronic renal failure. From the obtained results, serum glucose levels were significantly increased in L-arginine fed-rats, as compared to negative control group. Obviously, uncontrollable increase in serum total cholesterol and triglycerides lead to excessive increase in serum glucose level.

All experimental diets regulated the elevation of serum glucose levels except treatment with MPD only, which showed no significant reduction in serum glucose levels, as compared to CRF rats. The strongest action against the elevation of serum glucose levels was recorded in CRF rats treated with MPD containing $6 \%$ Arabic gum and $2 \%$ turmeric. It was remarkable that the higher doses were effective than lower doses. Our results are consistently agreed with previous studies by Giordano et al.(2014 )who confirmed that medium protein diet (MPD) did not affect glycaemia in diabetic patients, and did not change glucose metabolism in both animals and humans (Mudaliar and Henry 1996 and Arimura et al. 2013).

These results are in harmony with those obtained by Laquatra and Gerlach (1990) who demonstrated that other complications of chronic renal failure is glucose intolerance due to the prepheral tissue resistance to insulin action. Similarly, Evans et al. (2002) emphasis the relationship between oxidative stress and insulin resistance due to hyperglycemia. Recently, Banerji and Banerjee (2016) mentioned that turmeric decreased blood glucose level, has hypoglycemic effect, and helps controlling type 2 diabetes mellitus in advanced - stage patients by its effect as a strong antioxidant that inhibits oxidative stress, inflammation and immune dysfunctions. This positive effect of turmeric due to improvement of antioxidant enzyme activities (Robertson, 2009).The reduction in serum glucose level by Arabic gum is may be due to its content of dietary fiber, which associated with lowering caloric density of food (Schneeman 1987).Recently, Nasir (2014) reported that Arabic gum reduced serum glucose by decreasing glucose absorption. 
Table 4.Effect of medium protein diet containing two levels from turmeric, Arabic gum and their combination on serum glucose and liver enzymes of chronic renal failure rats

\begin{tabular}{|c|c|c|c|c|}
\hline \multirow{2}{*}{\multicolumn{2}{|c|}{ Parameters }} & \multirow{2}{*}{$\begin{array}{c}\text { Glucose } \\
\text { mg/dl }\end{array}$} & \multicolumn{2}{|c|}{ Liver enzymes (U/L) } \\
\hline & & & AST & ALT \\
\hline \multirow{2}{*}{\multicolumn{2}{|c|}{ Control (-ve) }} & $83.203^{f}$ & $58.521^{\mathrm{h}}$ & $20.763^{\mathrm{g}}$ \\
\hline & & \pm 3.025 & \pm 1.869 & \pm 1.457 \\
\hline \multirow{2}{*}{\multicolumn{2}{|c|}{ Control (+ve) }} & $145.010^{\mathrm{a}}$ & $103.021^{\mathrm{a}}$ & $60.610^{\mathrm{a}}$ \\
\hline & & \pm 5.724 & \pm 4.035 & \pm 3.423 \\
\hline \multirow{2}{*}{\multicolumn{2}{|c|}{ Only }} & $147.928^{a}$ & $94.948^{\mathrm{b}}$ & $55.370^{\mathrm{b}}$ \\
\hline & & \pm 5.973 & \pm 3.645 & \pm 3.555 \\
\hline \multirow{12}{*}{ 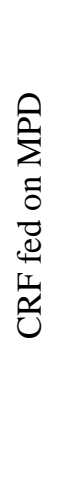 } & Containing $3 \%$ Arabic gum & $138.228^{\mathrm{b}}$ & $87.036^{\mathrm{c}}$ & $49.836^{\mathrm{c}}$ \\
\hline & & \pm 5.721 & \pm 2.957 & \pm 4.328 \\
\hline & Containing $6 \%$ Arabic gum & $128.605^{c}$ & $77.205^{\mathrm{e}}$ & $43.648^{\mathrm{de}}$ \\
\hline & & \pm 3.761 & \pm 2.782 & \pm 2.876 \\
\hline & Containing $1 \%$ turmeric & $135.171^{\mathrm{b}}$ & $82.686^{\mathrm{d}}$ & $46.316^{\mathrm{cd}}$ \\
\hline & & \pm 5.022 & \pm 3.179 & \pm 3.607 \\
\hline & Containing $2 \%$ turmeric & $121.695^{\mathrm{d}}$ & $72.775^{\mathrm{f}}$ & $40.506^{\mathrm{e}}$ \\
\hline & & \pm 2.838 & \pm 2.486 & \pm 3.304 \\
\hline & Containing $3 \%$ Arabic gum and $1 \%$ & $124.085^{\mathrm{cd}}$ & $76.443^{\text {ef }}$ & $41.255^{\mathrm{e}}$ \\
\hline & turmeric & \pm 4.334 & \pm 3.639 & \pm 2.793 \\
\hline & Containing $6 \%$ Arabic gum and $2 \%$ & $106.628^{\mathrm{e}}$ & $65.928^{\mathrm{g}}$ & $35.198^{f}$ \\
\hline & turmeric & \pm 3.858 & \pm 3.731 & \pm 11.449 \\
\hline
\end{tabular}

CRF: Chronic Renal Failure MPD :Medium Protein Diet

Values are expressed as means $\pm \mathrm{SD}$.

Values at the same column with different letters are significant at $\mathrm{P}<0.05$.

Most of earlier studies demonstrated that chronic renal failure is associated with impairment of causes multi-organ disturbance especially liver functions as elevation of ALT and AST enzymes (Mariusz et al. 1996; Yokozawa et al. 2003 and Kawai et al. 2006). With respect to liver functions, it could be observed that CRF rats produced significant increase in serum AST and ALT enzymes in comparable to healthy rats. Administration of all tested diets revealed significant reductions of AST and ALT enzymes. It could be stated that the higher doses of Arabic gum and tumeric were effective than the lower doses when they supplemented to MPD.

These results are in keeping with previous study by Ki Haw and Keum Ran( 2005) who reported that curcumin reduced hepatotoxicity by improvement of liver function in $\mathrm{CCl} 4$ treated rats. Recently, Lee et al. (2016) indicated that hepatic damage improved by treatment of turmeric extract as it regulated serum ALT and AST, indicating liver protection. By inhibition of oxidative stress and formation of reactive oxygen species (Behrman et al. 2001). At the same subject, curcumin, the main ingredient of turmeric has medicinal properties that it has protective effect against liver disease (Nayeri et al. 2017) by decreasing expression of intestinal cytochrome P450 3A (Zang et al. 2007).
Treatment of diabetic rats with Arabic gum significantly reduced liver alanine transaminase (ALT) and aspartate transaminase (AST) activity (Ahmed et al. 2015), this effect is may be due to antioxidant capacity of Arabic gum, which cause stability of cell membrane and protection of enzyme leakage (Thabrew et al. 1987).

Results in Table (5) showed the effect of medium protein diet containing two levels from turmeric, Arabic gum and their combination on lipid profile including (cholesterol, triglycerides, high density lipoproteincholesterol HDL-C, low and very low density lipoprotein-cholesterol (LDL-C\& VLDL-c) of rats suffering from chronic renal failure.

From the obtained results, it was observed that; impairment in renal functions in chronic renal failure as a results of L- arginine -fed diet produced some complications as dyslipidemia ; higher values of TC,TG,LDL and VLDL- C and on contrast lower value of HDL-C. These results are in accordance with findings by (Sing et al. 2006 and Rutkowski et al. 2006).

There were significant reductions in serum TC, TG, LDL-C and VLDL-C values and significant increases in serum HDL-C values in all treated groups as compared to positive control group. It was remarkable that, the 
Table 5. Effect of medium protein diet containing two levels from turmeric, Arabic gum and their combination on lipid profile of chronic renal failure rats

\begin{tabular}{|c|c|c|c|c|c|c|}
\hline \multirow{2}{*}{\multicolumn{2}{|c|}{ Groups }} & \multicolumn{5}{|c|}{ Lipid profile (mg/dl) } \\
\hline & & $\mathrm{TC}$ & TG & HDL-C & LDL-C & VLDL-C \\
\hline \multirow{2}{*}{\multicolumn{2}{|c|}{ Control (-ve) }} & $82.535^{h}$ & $35.686^{\mathrm{g}}$ & $50.230^{\mathrm{a}}$ & $25.169^{h}$ & $7.136^{\mathrm{g}}$ \\
\hline & & \pm 3.926 & \pm 2.594 & \pm 2.898 & \pm 3.828 & \pm 0.518 \\
\hline \multirow{2}{*}{\multicolumn{2}{|c|}{ CRF (+ve control) }} & $139.080^{\mathrm{a}}$ & $70.186^{\mathrm{a}}$ & $23.896^{\mathrm{h}}$ & $101.146^{\mathrm{a}}$ & $14.036^{\mathrm{a}}$ \\
\hline & & \pm 3.436 & \pm 2.859 & \pm 3.419 & \pm 4.873 & \pm 0.571 \\
\hline \multirow{2}{*}{\multicolumn{2}{|c|}{ Only }} & $129.741^{\mathrm{b}}$ & $64.935^{\mathrm{b}}$ & $28.236^{\mathrm{g}}$ & $88.503^{b}$ & $13.002^{\mathrm{b}}$ \\
\hline & & \pm 2.097 & \pm 2.261 & \pm 2.874 & \pm 3.820 & \pm 0.436 \\
\hline \multirow{2}{*}{\multicolumn{2}{|c|}{ Containing $3 \%$ Arabic gum }} & $120.125^{\mathrm{c}}$ & $57.686^{\mathrm{c}}$ & $33.890^{f}$ & $74.697^{\mathrm{c}}$ & $11.537^{\mathrm{c}}$ \\
\hline & & \pm 2.705 & \pm 3.535 & \pm 2.943 & \pm 5.012 & \pm 0.707 \\
\hline \multirow{10}{*}{ 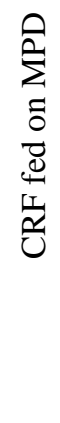 } & \multirow[t]{2}{*}{ Containing $6 \%$ Arabic gum } & $104.575^{\mathrm{e}}$ & $51.390^{\mathrm{d}}$ & $37.958^{\mathrm{de}}$ & $56.338^{\mathrm{e}}$ & $10.278^{\mathrm{d}}$ \\
\hline & & \pm 3.530 & \pm 2.624 & \pm 1.899 & \pm 4.851 & \pm 0.524 \\
\hline & \multirow[t]{2}{*}{ Containing $1 \%$ turmeric } & $113.550^{\mathrm{d}}$ & $53.081^{\mathrm{d}}$ & $35.391^{\mathrm{ef}}$ & $67.542^{\mathrm{d}}$ & $10.616^{\mathrm{d}}$ \\
\hline & & \pm 3.021 & \pm 3.661 & \pm 2.292 & \pm 4.722 & \pm 0.732 \\
\hline & \multirow[t]{2}{*}{ Containing $2 \%$ turmeric } & $99.556^{f}$ & $46.226^{\mathrm{e}}$ & $39.961^{\mathrm{cd}}$ & $50.349^{\mathrm{f}}$ & $9.245^{\mathrm{e}}$ \\
\hline & & \pm 3.179 & \pm 3.767 & \pm 1.622 & \pm 3.907 & \pm 0.753 \\
\hline & \multirow{2}{*}{$\begin{array}{l}\text { Containing } 3 \% \text { Arabic gum } \\
\text { and } 1 \% \text { turmeric }\end{array}$} & $101.591^{\mathrm{ef}}$ & $46.775^{\mathrm{e}}$ & $41.566^{\mathrm{bc}}$ & $50.670^{f}$ & $9.355^{\mathrm{e}}$ \\
\hline & & \pm 2.725 & \pm 3.981 & \pm 2.077 & \pm 3.516 & \pm 0.796 \\
\hline & \multirow{2}{*}{$\begin{array}{l}\text { Containing } 6 \% \text { Arabic gum } \\
\text { and } 2 \% \text { turmeric }\end{array}$} & $90.490^{\mathrm{g}}$ & $42.476^{f}$ & $43.350^{\mathrm{b}}$ & $38.644^{\mathrm{g}}$ & $8.495^{\mathrm{f}}$ \\
\hline & & \pm 2.494 & \pm 2.825 & \pm 1.705 & \pm 3.347 & \pm 0.565 \\
\hline
\end{tabular}

TC: TotalCholesterol TG: Triglyceride HDL-C: High Density Lipoprotein-Cholesterol

LDL-C: Low Density Lipoprotein-Cholesterol VLDL-C: Very low density lipoprotein-cholesterol

CRF:Chronic Renal Failure MPD:Medium Protein Diet

Values are expressed as means $\pm \mathrm{SD}$.

Values at the same column with different letters are significant at $\mathrm{P}<0.05$.

higher doses were more effective than the lower. The most hypolipidemic effects were recorded in CRF rats treated with MPD containing 6\% Arabic gum and 2\% turmeric. These results are in board agreement with the results of Peter (2000) who demonstrated that turmeric has cholesterol-lowering effect. This effect of turmeric is due to its content of saponins, which have cholesterol -lowering effect (Gills, 1992).

Similarly, Ki Haw and Keum Ran( 2005) reported that curcumin improved lipid profile in $\mathrm{CCl} 4$ treated rats by decreasing levels of triglycerides, total cholesterol and low density lipoprotein. Recently, Lee et al. (2016) revealed that administration of turmeric extract increased hepatic HDL-C in CCl4-induced liver damage by enhancing antioxidation.

Ali et al. (2009) reported that, the reduction in serum lipids by Arabic gum is may be due to its content of dietary fiber which associated with the beneficial effect of fat metabolism. Also, Arabic gum in combination between two types of Arabic gum decreased total cholesterol and LDL-C in normal rats (Eqbal and Aminah 2014), this lipid-lowering effect in animal (Gallaher et al. 1993) and human (Superko et al. 1988) because of its content of non -starch polysaccharides. .Recently, Ahmed et al. (2015) confirmed hypolipidemic effect of Arabic gum in diabetic rats due to its dietary fiber.

\section{CONCLUSION}

This study concluded that; treatment of chronic renal failure rats with different experimental diets revealed improvement in biomarkers of CRF rats especially renal and liver functions. The data was recorded strongly with combination of turmeric, Arabic gum and medium protein diet at higher doses.

\section{REFERENCES}

Adams, L. G., D. j.Polzin, C. A.Osborne, T. D. O. Brein and T. H. Hosteetter. 1994. Influence of dietary protein/calorie intake on renal morphology and function in cats with $5 / 6$ nephrectomy. Lab. Invest. 70(3): 347-357.

Ahmed, A. A., J. S.Fedail, H. H.Musa, A. A.Kamboh, A. Z. Sifaldin and T. H. Musa. 2015. Gum Arabic extract protect against hepatic oxidative stress in alloxan induced diabetes in rats. Pathophysiology. $\mathrm{Xxx}(\mathrm{xxx}-\mathrm{xxx})$. Article in press.

Ali, B. H., I. Al-Husseni, S. Beegam, A. Al-Shukaili, A. Nemmar and S. Schierling. 2013. Effect of Gum Arabic on Oxidative Stress and Inflammation in AdenineInduced Chronic Renal Failure in Rats. PLoS ONE 8(2): e55242. 
Ali, B. H., A.Ziada and G.Blunden. 2009. Biological effects of gum Arabic : a review of some recent research. Food Chem. Toxicol. 47(1): 1-8.

Al-Majed, A. A., A. M. Mostafa, A. C. Al-Rikabi and O. A.Al-Shabanah. 2002. Protective effects of oral Arabic gum administration on gentamicin-induced nephrotoxicity in rats. Pharmacol.Res. 46(5):445-451.

Antonyan, A., A.Dec, L. A. Vitali, R.Pettinari, F.Marchetti and M. R. Gigliobianco. 2014. Evaluation of (areane) $\mathrm{Ru}(\Pi)$ complex of curcumin as inhibitors of dipeptidyl peptidase IV. Biochemistry, 99:146-52.

Arimura, E., M. Horiuchi and H Kawaguchi. 2013. Lowprotein diet improves blood and urinary glucose levels and renal manifestations of diabetes in C57BLKS-db/db mice. Eur. J. Nutr. 52(2):813-24.

Banerji, S. and S.Banerjee. 2016. A formulation of grape seed, Indian gooseberry, turmeric and fenugreek helps controlling type 2 diabetes mellitus in advanced- stage patients. Eru. J. integr. Med. $x x x(x x x-x x x)$ article in press.

Bartels, H. and M.Bohmer. 1971. Creatinine standard and measurement of serum creatinine with picric acid. Clin. Chem, Acta. 32:81.

Baylis, C. 2006. Nitric oxide deficiency in chronic renal disease. J. Clin. Pharma. 62:123-130.

Behrman, H. R., P. H.Kodman, S. I. Preston and S. Gao. 2001. Oxidative stress and the ovary. J. SocGynecol Investing., 8( 1Supp Proceedings).S 40-42.

Biswas, S. K., D. McClure, L. A. Jimenez, I. L.Megson and I. Rathman. 2005. Curcumin induces glutathione biosynthesis and inhibits NF- kappa B activation and interlekin-8 release in alveolar epithelial cells: mechanisms of free radical scavenging activity. Antioxidant Redox Signaling. 7:32-41.

Bliss, D. Z., T. P.Stein, C. R. Schleifer and R. G.Settle. 1996. Supplementation with gum Arabic fiber increases fecal nitrogen excretion and lowers serum urea nitrogen concentration in chronic renal failure patients consuming a low-protein diet. Am. J.Clin.Nutr. 63(3):392-398.

Brunori, G., B. F.Viola and G.Parrinello. 2007. Efficacy and safety of a very-low-protein diet when postponing dialysis in the elderly: a prospective randomized multicenter controlled study. Am. J .Kidney Dis. 49(5):569-80.

Castaneda, C., P. L.Gordon, K. L.Uhlin, A. S. Levey, J. J. Kehayias, J. T. Dwyer, R. A.Fielding, R.Roubenoff and M. F. Singh. 2013. Resistance training to counteract the counteract the catabolism of a low-protein diet in patients with chronic renal insufficiency. American College of Physician-American Society of Internal Medicine. 965976.

Chan, W., R. J.Krieg, E. P. Norkus and J. C. Chan. 1998. Alpha-Tocopherol reduces proteinuria, oxidative stress and expression of transforming growth factor beta 1 in IgA nephropathy in the rat. Mol Genet. Metab. 63(3): 224-229.

Chapman, D. G., R.Castilla and J. A. Chambell. 1959. Evaluation of proteinin foods. I.A. Method for the determination of protein efficiency ratio. Can. J. Biochem.Physiol, 37: 679-686.

Christoph, B., J. Hans and B.Stefen. 2002. Serum uric acid as an independent predictor of mortality in patients with angiographically proven coronary artery disease. Am. J. Cordial. 89: 12-17.

Curcio, F., I.Pegoraro, P. Dello Russo, E.Falleti, G. Perrella and A. Cerielio. 1995. Sod and GSH inhibit the high glucose-induced oxidative damage at the PDGF increased secretion in cultured human endothelial cells. Thromb. Haemodt. 74: 969-973.

Eqbal, M. A. D. and A.Aminah. 2014. Blood lipid profile and liver lipid peroxidation in normal rat fed with different concentrations of Acacia Senegal and AcaiaSeyal. International Journal of Nutrition and Food Engereeinig. 8(11): 12921297.

Evans, J. L., I. D.Goldfine, B. A.Maddux and G. M. Grodsky. 2002. Oxidative stress and stress activated pathway: a unifying hypothesis of type 2 diabetes. Endocr Rev. 23: 599- 622.

Eyre, S., P. O.Attman, and B.Haraldsson. 2008. Positive effects of protein restriction in patients with chronic kidney disease.J .Rena. Nutr. 18(3):269-80.

Gallaher, D. D. C. A. Hassel and K. J. Lee. 1993. Relations between viscosity of hydroxypropyle methylcellulose and plasma cholesterol in hamsters. J. Nutri. 123:732-738.

Gerich. 2001. Renal gluconeogensis: its importance in human glucose homostatis. Diabetic. Care. 24: 382, and Wikipedia. Kidney.2006 at http://en.wikipedia. org/wiki/kidney.

Giebisch, G. 2007. Renal potassium transport: mechanisms and regulation. Am.J. renal Physiology. 274:817-833.

Gills, L. S. 1992. Entho Medical users of plants in Nigeria. Pp. 276 African press, Benine City.

Giordano, M., T.Ciarambino, P.Castellino, A.Cataliotti, L.Malatino, N.Ferrara, C. Politi and G.Paolisso. 2014. Long-term effects of moderate protein diet on renal function and grade inflammation in type li diabetic elderly with chronic kidney disease. J. Nutri.03.007.

Haisman, P. and B. R. Muller. 1977. Quantitative enzymatic colorimetric determination of uric acid in serum.Clin. Chem. 26: 227.

Hatch, F. T. and R. S. Lees. 1986. Practical methods for plasma lipoprotein analysis. Adv. Lipid, Res. 6: 1-68.

Henry, R. J. 1964. Calorimetric Methods of Total Protein. $J$. Clin. Chem.;Harpre, Row Publishers, New York. P. 181.

Henry, J. B., M. K.Todd, L. U. Sanford and S. G. davidsohn. 1974. Clinical Diagnosis and Measurement by Laboratory Methods. $16^{\text {th }}$ Ed. W. B. Saunders and CO., Philadelphia. P. A. PP. 260.

Henry, J. B., D. A.Nelson, R. H.Tomar, J. A. Washingoton and G. A. Threatth. 1991. Clinical Diagnosis Mmanagement by Laboratoty Methods.18th Ed. W. B. Saunders Company, Harcot Brace Jovanoich, Inc. 
Hilton, P. J., J.Taylor, L. G.Forni and D. F. Treacher. 1998. Bicarbonate-based haemofiltration in the management of acute renal failure with lactic acidosis. QJM, 91:279-83.

Hsu, C.Y., M. F.Pai, Y. S.Peng, C. K.Chiang, T. I. Ho and K. Y. Hung. 2004. Serum uric acid levels show a "J. Shaped' associated with all-causes mortality in haemodialysis patients. Nephrol.; Dial., Transplant.,19(2): 457 -462.

Hus, C. Y. and G. M. Chertow. 2002. Elevation of serum phosphorus and potassium in mild to moderate chronic renal insufficiency. Nephro. Dial. Transplant. 19(2): 457462.

Joe, B. M., M.Vijaykumar and B. R.Lokesh. 2004. Biological properties of curcumin cellular and molecular mechanisms of action. Critical Reviews in Food Science and Nutrition. 44: 97:111.

Kakkar, R., J.Kalra, S. V. Mantha and K.Prasad. 1995. Lipid peroxidation and active of antioxidant enzymes on diabetic rats .Mol. Cell. Biochem. 151 :113-119.

Kawai, T., Y.Yokoyam, M.Nagino, T.Kitagawa and Y. Nimura. 2006. Is there any effect of renal failure on the hepatic regeneration capacity followinig partial hepatectomy in rats? Biochem.Biophys.Res.Commun. 3116.

Khajehdehi, P., B. Zanjaninejad, E.Aflaki, M. A. Nazarinia, F.Azad, L.Malekmakan and G.R. Dehganzadeh. 2012. Oral supplementation of turmeric decreased proteinuria, hematuria, and systolic blood pressure in patients suffering from relapsing or refractory lupus nephritis : a randomized and placeabo-controlled study. J. Renal. Nutri. 22: 50-57.

Ki Haw, J. and S. Keum Ran. 2005. Protective effect of curcumin and Aqueous extract of onchengyeum on CCl4induced hepatotoxicity.Pharma., 13(4): 232-239.

Kim, H. J., N. D. Vaziri and K.Norris. 2010. High-calorie diet with moderate protein restriction prevents cachexia and ameliorates oxidative stress, inflammation and proteinuria in experimental chronic kidney disease. Clin. Exp. Nephrol. 14(6):536-47.

Kulkarni, S., K.Maske, M.Budre and R.Mahajan. 2012. Extraction and purification of curcuminoids from turmeric (Curcuma longa L.). Int. J. Pharmacol. Pharm. Tech. 1: 2277-3436.

Laquatra, I. and M. G. Gerlach. 1990. Nutrition in Clinical Nursing.1st Ed., Delmar Publishers Inc., Canda.

Lee, C. J., G. H.Lee, J. H.Seok, G. M.Hur, Y. C. Park and I. C. Seol. 2003. Effect of baicatein, berberine, curcumin and hespirdin on mucin release from airway goblet cell. Planta Med. 69: 523-6.

Lee, H-Y., S.W. Kim, G.H.Lee, M.K.Choi, H.W.Jung, Y.J.Kim, H-J. Kwon. And H.J. Chae. 2016. protect against chronic CCl4-induced liver damage by enhancing antioxidation. BMC Compelementary and Alternative Medicine. 16:316.

Lee, R. and D.Nieman. 1996. Nutritional assessment 2th Ed., Mobsy. Atimes. Mirror Co. Louis, Missouri.
Luthra, P. M, R.Singh and R.Chandra. 2001. Therapeutic uses of curcumic longa (turmeric).Indian Journal of Clinical Biochemistry. 16: 153 - 160.

Mahmoud, M. F., A. A. Diaai and F.Ahmed. 2012. Evaluation of the efficacy of ginger, Arabic gum and boswellia in acute and chronic renal failure. InformahealthcareUSA,Inc. renal failure. 34(1): 73-82.

Mariusz, K., S.Miroslaw, N.Zhenmin, Z.Guoxiang and G.Shaul. 1996. Abnormalities in hepatic lipase in chronic renal failure. The American Society for Clinical Investigation, Iinc. 97(10):2167-2173.

Maroni, B. J. and W. E. Mitch. 1997. Role of nutrition in prevention of the progression of renal disease. Annu. Rev. Nutr. 17:435-55. [PMID: 9240935].

Morris, S. M. 2004. Enzymes of arginine metabolism. J. Nutr. 134:2743S-2747S.

Mudaliar, S. R. and R. R. Henry. 1996. Role of glycemic control and protein restriction in clinical management of diabetic kidney disease. Endocr Pract. 2(3):220-6.

Naksuriya, O., S.Okonogi, R. M.Schiffelers and W. E. Hennink. 2014. Curcumin nano-formulations: a review of pharmaceutical properties and preclinical studies and clinical data related to cancer treatment. Biomaterials. 35 : 3365-83.

Nankivell, B. J., Y. C. Tay and R. A.Boadle. 1994. Dietary protein alters tubular iron accumulation after partial nephrectomy. Kidney.Int. 45(4):1006-13.

Nasir, O. 2014. Effect of Gum Arabic (Acacia Senegal) on Glucose Metabolism and Body Weight Gain in Mice. Journal of Biology, Agriculture and Healthcare www.iiste.org ISSN 2224-3208 (Paper) ISSN 2225093X(Online) Vol.4, No.9, 34.

National Kidney Foundation. 2000. Clinical practice guidelines for nutrition in chronic renal failure. K/DOQI, National Kidney Foundation. Am. J. Kidney Dis. 35: 1S.

Nayeri, A., S.Wu, E.Adams, C.Tanner, J.Meshman, I.Saini and W. Reid. 2017. Acute calcineurin inhibitor nephrotoxicity secondary to turmeric intake: A case report. Department of Medicine, University of California, Los Angleles, California.

Nguyen, M. K. and I.Krutz, 2005. A new formula for predicting alterations in plasma sodium concentration in peritoneal dialysis. Am. J. Physiol. Renal Physiol. 288(6): 1113-1117.

Peter, K. V. 2000. Informatics on turmeric and ginger. India Spices 36(s and 3): 12-14.

Pedrini, M. T., A. S.Levey, J.Lau, T. C.Chalmers and P. H.Wang. 1996.The effect of dietary protein restriction on the progression of diabetic and non diabetic renal diseases: a meta-analysis. Ann. Intern. Med..124:627-32. [PMID: 8607590].

Platel, K. and K. Srinivasan. 1996. Influence of dietary spices or their active principles on digestive enzymes of small intestinal mucosa in rats. Int. J. Food. Sci. Nutr.47:55-9. 
Prasad, S. and B. B. Aggarwal, 2011. Turmeric, the golden spice: from traditional medicine to modern medicine. In: Benzie, I.F.F., Wachtel-Galor, S. (Eds.), Herbal Medicine: Biomolecular andClinical Aspects. CRC Press, Taylor \& Francis Ltd., Boca Raton (FL).

Rahman, M. F. M. K.Siddiqui and K. Jamil. 2001. Effects of Vepacide (Azadirachtaindica) on asp artate and al anine aminotransferase profiles in a subchronic study with rats .Hum Exp. Toxicol. 20.(5): 243-249.

Reitman, S. and S.Frankel.1975. Colorimetric determination of serum transaminase. Am. J. Clin. Path.28: 56.

Richmond, W. 1973. Calorimetric method of determination of total cholesterol and high density lipoprotein cholesterol. Clin. Chem.19: 1350-1356.

Robertson, R. P. 2009. Beta-cell deterioration during diabetes. What, $\mathrm{s}$ in the gun, trends endocrinol. Metab. 20:388-393.

Rozan, M.A., H.M Bayomy and E.G.Boriy. 2018. Effects of turmeric addition on chemical composition, antioxidant activity and sensory evaluation of lentil soup. Alexandria Science Exchange Journal .39 (1) : (1-6)

Rutkowski, P., A.Classed, K. Sebekova, U. Banter and A.Headl. 2006. Renal disease in obesity: the need for greater attention. J. Renal. Nutri.(16):216-223.

Sanders, P. W. 1995. L-Arginine and arginine in progressive renal failure. Blood Puri.13(3-4): 219-227.

Schneeman, B. O. 1987. Dietary fiber: comments on interpreting recent research. J. Am. Diet. Assoc.87:1163.

Schrier, R. W., D. C.Harris, L. Chan, J. I. Shaprio and Caramelo. 1988. Tublarhypermetabolism as a factor in the progression of chronic renal failure. Am. J. kidney Des. 12: 243-249.

Shivanoor, S. M. and M.David. 2014. Protective role of turmeric against deltamethrin induced renal oxidative damage in rats. Biomedicine \& preventive Nutrition. 543553.

Sing, D., R.Kaur, V.Chander and K.Chopra. 2006.Antioxidants in prevention renal disease. J. Med. Food. 9(4): 443-540.
Steel, R. G. and J. H.Torri. 1980. Principal and Procedures of Statistical, Biometrical Approach. Pbl. Mc Grew Hill Book Company. $2^{\text {nd }}$ ed. New York. U.S.A.

Stenvinkel, P., O. Heimbürger and C. H. Tuck . 1998. Apo(a)isoform size, nutritional status and inflammatory markers in chronic renal failure. Kidney Int. 53(5):1336-42.

Superko, H. R., W. L.Haskell, L.Sawrey- Kubicek and J. W. Farquhar. 1988. Effects of solidand liquid guar gum on plasma cholesterol and triglyceride concentrations in moderate hypercholesterolemia. Cardiol. 62: 51- 55.

Tai, C. C. and S. T. Ding. 2010. N-3 polyunsatureted fatty acids regulate lipid metabolism through several inflammation mediators: mechanisms and implications for obesity prevention. J NutrBiochem . 21(5):357-63.

Thabrew, M. I., P. D. Joice and W.Rajatissa. 1987. A comparative study on the efficacy of PavettaindicaandOsbechikactandra in the treatement of liver dysfunction. Planta. 53:239-241.

Trachtman, H., J. C.Chan, W.Chan, E.Valderraman, R.Brandt, P. Wakely, S.Futterwei, J.Maesaka and C.Ma. 1996. Vitamin $\mathrm{E}$ ameliorats renal injury in an experimental model of immunoglobulin A nephropathy. Pediatr. Res. 40(4): 620-626.

Trinder, P. 1969. Determination of glucose in blood using glucose oxidase with an alternative oxygen acceptor. Ann. Clin. Biocheme. 6: 24-28.

Wahalefeld, A. W. 1974. Colorimetric method of determination of triglycerides in serum or plasma. Academic Press, New York, Vol. 5, pp: 1831- 1838.

Yokozawa, T., E. J. Cho and T.Nakagawa. 2003. Influence of green tea polypheol in rats with arginine- induced renal failure. J.Agric. Food Chem. 51:2421-2425.

Younes, H., K.Garleb, S.Behr, C.Rémésy and C. Demigné. 1995. Fermentable fibers or oligosaccharides reduce urinary nitrogen excretion by increasing urea disposal in the rat cecum. J Nutr. 125(4):1010-1016.

Zang, W., T. M. Tan and I. Y. Lim. 2007. Impact of curcumin- induced changes in P-glycoprotein anf CYP3Aexperssion on the pharmacokinetics ofperoralceliprotol and midazolam in rats. Drug.Metab.Dispos. 35:110-5. 


\section{الملخص العربي}

تقييم فعالية النظام الغذائي متوسط البروتين والكركم والصمغ العربي علي الفشل الكلوي المزمن ابتسام فتح محمود عمر ، دعاء إبر اهيم محمد قابيل

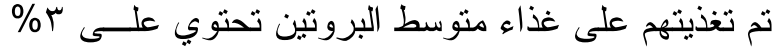

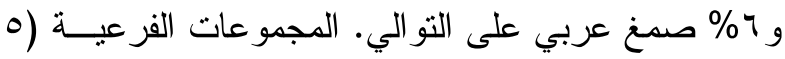

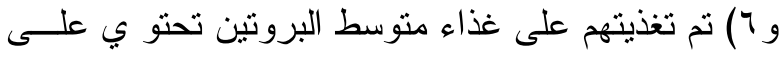

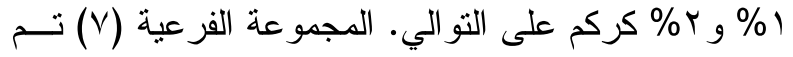

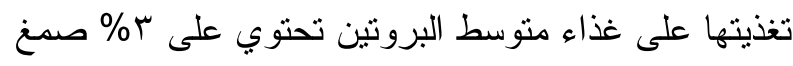

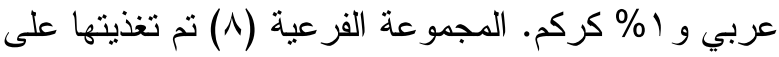

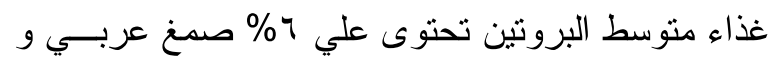

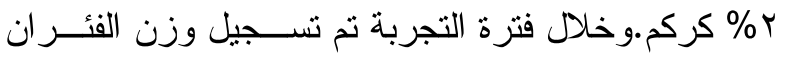

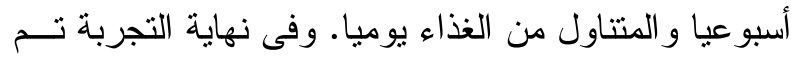

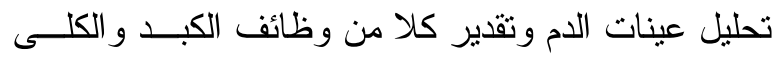
ومستوى سكر الدم ونسبة البروتين الكلى و أملاح الصوديوم و البوتاسيوم ودهون الدم. و أظهرت النتائج التأثير الايجابي

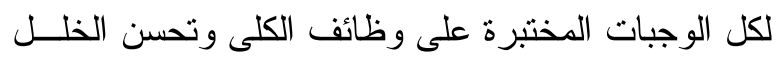

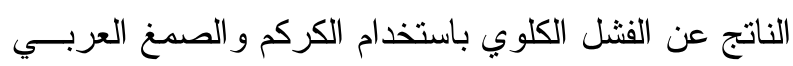

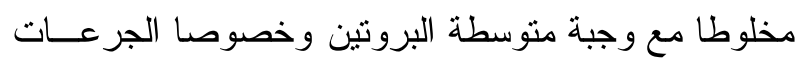

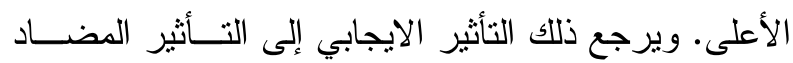
للأكسدة لكلا من الكركم و الصمخ العربي. الكلمات المفتاحية: فشل كلوى مزمن - ارجينين - نظام غذائي منوسط البروتين - كركم - صدغ عربي - وظائف كلي - جلوكوز - صورة الدهن - انزيمات الكبد.
الفشل الكلوي هو حدوث خلل في وظائف الكلى نتيجـــة

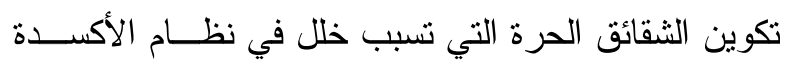
داخل الجسم مما يؤدى إلى حدوث التلف التأكسدي. و ويعتبر الكركم و الصمغ العربي من المكونات ذات تـأثير مضـــاد

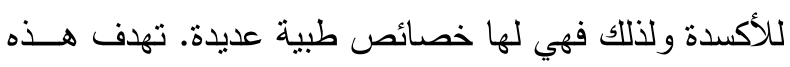

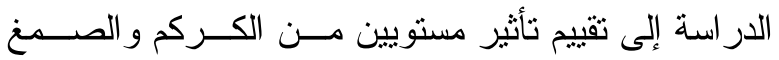
العربي وخليطهما في وجود الوجبات متوســـة البــروتين علي الفئران المصابة بالفشل الكلوي المزمن.استخدمت في لوني

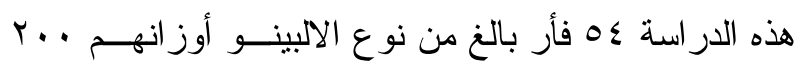

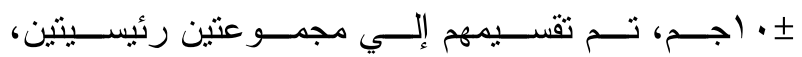

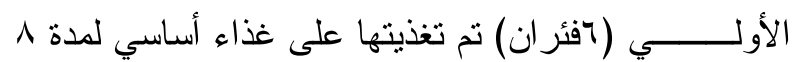

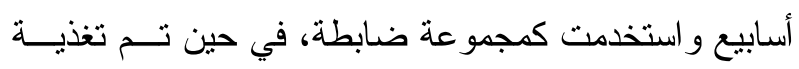

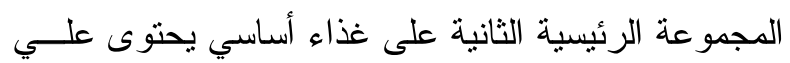

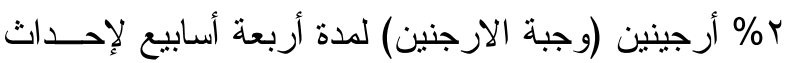

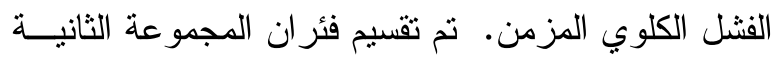

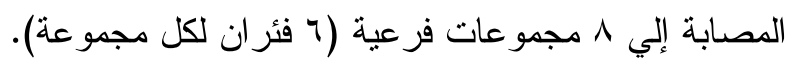
المجدوعة الفرعية (1) تم تغذيتها على وجبــــة الارجينـين

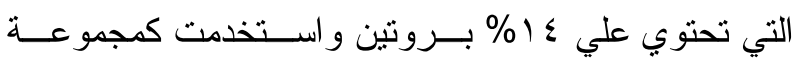
ضابطة مصابة. المجموعة الفرعية (r) تم تغــذيتها علىى

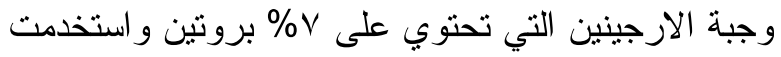
كمجموعة منوسطة البروتين. المجموعات الفرعية (ب و ع) 